\title{
Inhibition of myeloperoxidase by synovial fluid and
} serum

\author{
B Dularay, C M Yea, C J Elson
}

\begin{abstract}
An inhibitor of myeloperoxidase has been identified in the synovial fluids and sera from patients with rheumatoid arthritis and sera from normal subjects. Initially, these fluids were found to inhibit stimulus induced degranulation of polymorphonuclear leucocytes independently of the stimulating agent. Subsequently, the fluids were shown to inhibit the released enzyme rather than the degranulation response of polymorphonuclear leucocytes. Both rheumatoid and normal serum samples contained high concentrations of the inhibitor but the concentrations were lower in rheumatoid synovial fluids. The inhibitory activity seemed to be specific for peroxidase as the fluids did not inhibit $\beta$-glucuronidase activity. A protein of relative molecular mass $\left(M_{r}\right) 150 \mathrm{kd}$ was purified from synovial fluid by affinity chromatography on myeloperoxidase-Sepharose. It is concluded that serum and synovial fluid contain a novel myeloperoxidase inhibitor, which acts by binding to myeloperoxidase and thereby prevents myeloperoxidase releasing oxidative products in serum.
\end{abstract}

Since the discovery of large numbers of polymorphonuclear leucocytes ${ }^{1}$ in the joint fluid of patients with rheumatoid arthritis, considerable efforts have been made to determine the part played by these cells in the disease. It has been shown that blood polymorphonuclear leucocytes can be stimulated in vitro by a variety of agents, some of which are present in rheumatoid synovial fluids, to release enzymes and oxygen radicals, both of which are implicated as mediators of tissue damage. ${ }^{2-4}$ To determine whether rheumatoid synovial fluid polymorphonuclear leucocytes can release these products in vivo the ability of such leucocytes to make oxidative and degranulation responses in vitro has been examined. Polymorphonuclear leucocytes derived from synovial fluid showed enhanced oxidative responses compared with autologous blood leucocytes. ${ }^{5}$ In addition, interleukin-1, which is known to occur in rheumatoid synovial fluids, ${ }^{6} 7$ primed normal blood polymorphonuclear leucocytes to give augmented degranulation responses to suboptimal concentrations of stimuli. ${ }^{8}$ Contrary to our expectation, however, polymorphonuclear leucocytes derived from synovial fluid did not give enhanced degranulation responses to the stimuli tested. Indeed, in the presence of synovial fluid the degranulation response to known degranulating agents was inhibited. Inhibition was evident only when myeloperoxidase, but not $\beta$ glucuronidase, was used as a marker of degranulation. ${ }^{9}$ These results led us to suggest that a myeloperoxidase inhibitor exists in rheumatoid synovial fluids, and the purpose of this study was to test this hypothesis. The results show the existence of such an inhibitor in rheumatoid serum and synovial fluid as well as in normal human serum.

\section{Patients and methods PATIENTS}

Blood samples and synovial fluids were obtained from patients attending the rheumatology outpatients clinic at the Bristol Royal Infirmary. All patients with rheumatoid arthritis fulfilled the standard criteria for classical or definite rheumatoid arthritis. The patients were receiving a variety of non-steroidal anti-inflammatory and slow acting antirheumatic drugs. Of 21 patients studied, 13 were female (mean age $55 \cdot 7$ years, range 32-73), and eight were male (mean age $53 \cdot 8$ years, range $37-72$ ). Synovial fluids were obtained by therapeutic aspiration of inflamed knee joints which were free from bacterial infections. Samples of synovial fluid were also obtained from six patients with osteoarthritis. All synovial fluid samples were collected in 0.1 volume acid citrate dextrose and centrifuged at $1840 \mathrm{~g}$ for 10 minutes to remove cells. Synovial fluids free from cells were split into aliquots and stored at $-70^{\circ} \mathrm{C}$. Dialysis of synovial fluid was carried out in visking tubing (molecular weight cut off of $15 \mathrm{kd}$ ) against three changes of phosphate buffered saline (PBS) at $4^{\circ} \mathrm{C}$ over 24 hours.

Normal human serum was obtained from healthy volunteers and stored at $-20^{\circ} \mathrm{C}$.

POLYMORPHONUCLEAR LEUCOCYTE PREPARATION Peripheral blood was collected from volunteers or patients in $3.8 \%$ sodium citrate and the polymorphonuclear leucocytes isolated by a modification of the method of Dooley et al. ${ }^{10}$ Briefly, blood was diluted $1: 1 \cdot 3$ (v/v) with $6 \%$ dextran (Fisons) and PBS containing $4 \%(w / v)$ sodium citrate, pH 7·3. After 45 minutes' incubation at room temperature the leucocyte rich supernatant was centrifuged at $170 \mathrm{~g}$ for 10 minutes. The cells were resuspended in a $50 \%$ solution of Percoll (Sigma) and layered onto a discontinuous gradient composed of $65 \%$ and $82.5 \%$ Percoll. After centrifugation at $270 \mathrm{~g}$ for 20 minutes the polymorphonuclear leucocytes present at the $65 \%$ and $82.5 \%$ interface were removed and washed twice before use. Poly- 
morphonuclear leucocytes were isolated from synovial fluid in the same way except that the dextran sedimentation step was omitted.

The cells were resuspended in Hanks's balanced salt solution (HBSS) (136 mM $\mathrm{NaCl}, 5.4 \mathrm{mM} \mathrm{KCl}, 1.0 \mathrm{mM} \mathrm{MgCl}_{2} \cdot 6 \mathrm{H}_{2} \mathrm{O}$, $1.0 \mathrm{mM} \mathrm{CaCl} \cdot 2 \mathrm{H}_{2} \mathrm{O}, 5.5 \mathrm{mM}$ glucose, $10 \mathrm{mM}$ HEPES ( $N$-2-hydroxyethylpiperazine- $N^{\prime}-2$ ethanesulphonic acid) $\mathrm{pH} 7 \cdot 3$, to give $2 \times 10^{7}$ cells $/ \mathrm{ml}$. The cells prepared by this method were more than $98 \%$ polymorphonuclear leucocytes and $99 \%$ viable based on trypan blue exclusion.

\section{POLYMORPHONUCLEAR LEUCOCYTE}

\section{DEGRANULATION}

Polymorphonuclear leucocytes were pretreated with $20 \mu \mathrm{g} / \mathrm{ml}$ cytochalasin B (Sigma; $1 \mathrm{mg} / \mathrm{ml}$ in dimethyl sulphoxide) for 10 minutes at room temperature. The treated cells $\left(10^{6} / 50 \mu \mathrm{l}\right)$ were incubated with HBSS containing $10 \mathrm{mg} / \mathrm{ml}$ human serum albumin (HSA-HBSS) (Sigma), and the stimulus, either $N$-formyl-methionylleucyl-phenylalanine (fMLP) $\left(2.5 \times 10^{-9}-2.5 \times\right.$ $\left.10^{-4} \mathrm{~mol} / \mathrm{l}\right)$, heat aggregated IgG $(0 \cdot 25-2 \cdot 0$ $\mathrm{mg} / \mathrm{ml})$, or platelet activating factor $(0.5-2.5$ $\mu \mathrm{g} / \mathrm{ml}$ ) for 30 minutes at $37^{\circ} \mathrm{C}$. The total reaction volume was $500 \mu \mathrm{l}$ and each reaction was set up in triplicate. The supernatant was assayed for activities of myeloperoxidase, lactate dehydrogenase, and in some cases $\beta$-glucuronidase. Enzyme release was expressed as a percentage of the maximum releasable determined by lysing polymorphonuclear leucocytes with $0.05 \%$ triton X-100 (Sigma) for two minutes. The supernatant was then assayed for myeloperoxidase, lactate dehydrogenase, and $\beta$-glucuronidase activities as described below.

$N$-Formyl-methionyl-leucyl-phenylalanine (Sigma) was dissolved in dimethyl sulphoxide and stored as a $1 \mathrm{mM}$ stock solution at $-70^{\circ} \mathrm{C}$. Heat aggregated IgG was prepared by dissolving Cohn 2 globulin fraction (Sigma) in PBS, pH $7 \cdot 3$, at $25 \mathrm{mg} / \mathrm{ml}$ and heating at $63^{\circ} \mathrm{C}$ for 40 minutes in a glass vessel. The aggregated IgG was cooled to $4^{\circ} \mathrm{C}$, split into aliquots, and stored at $-20^{\circ} \mathrm{C}$. Platelet activating factor (Sigma) was dried under nitrogen to remove chloroform and redissolved in HSA-HBSS at 5 $\mu \mathrm{g} / \mathrm{ml}$.

\section{ENZYME ASSAYS}

Polymorphonuclear leucocyte degranulation was measured by assaying the azurophil granule enzyme myeloperoxidase (EC 1.11.1.7) spectrophotometrically using the substrate tetramethylbenzidine in the presence of hydrogen peroxide by the method of Suzuki et al. ${ }^{11}$ The supernatant to be assayed was added to the

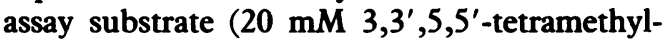
benzidine $(50 \mu \mathrm{l}), 0.03 \%(\mathrm{w} / \mathrm{v}) \mathrm{H}_{2} \mathrm{O}_{2}(20 \mu \mathrm{l})$, $0.01 \mathrm{M}$ sodium acetate buffer $\mathrm{pH} 5.2(50 \mu \mathrm{l})$, and PBS $(150 \mu \mathrm{l})$ and incubated for exactly five minutes at $37^{\circ} \mathrm{C}$. The reaction was terminated by the addition of $1 \mathrm{mM}$ sodium azide, followed

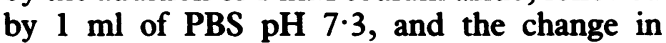
absorbance at $655 \mathrm{~nm}$ measured.

In some experiments the enzyme $\beta$-glucur- onidase (EC 3.2.1.31) was also assayed according to the method of Talalay et $a^{12}$ using the substrate $p$-nitrophenyl $\beta$-glucuronide.

As a measure of cell death lactate dehydrogenase (EC 1.1.1.27) was assayed with a standard assay kit (Boehringer). The initial rate of oxidation of diphosphopyridine nucleotide in the presence of $0.01 \mathrm{mM}$ sodium pyruvate was measured at $340 \mathrm{~nm}$.

SODIUM DODECYL SULPHATE-POLYACRYLAMIDE GEL ELECTROPHORESIS (SDS-PAGE)

SDS-PAGE was performed by the discontinuous buffer method of $\mathrm{Laemmli}^{13}$ using a $12 \%$ separating gel.

PURIFICATION OF HUMAN MYELOPEROXIDASE Human polymorphonuclear leucocytes were resuspended in PBS, sonicated on ice $(3 \times 10 \mathrm{~s}$, $50 \mathrm{~W}$ ), and membranes prepared by centrifugation (100 $000 \mathrm{~g}, 30$ minutes). After preextraction with $0.25 \%$ Lubrol PX/0.25\% sodium deoxycholate in $10 \mathrm{mM}$ glycine $(\mathrm{pH} 8.0)$ the leucocytes were extracted twice with $0.5 \%$ cetyltrimethyl ammonium bromide in $0.1 \mathrm{M}$ phosphate buffer, $\mathrm{pH} 7 \cdot 4$. The supernatant was collected and loaded onto a $12 \times 2 \mathrm{~cm}$ column of $\mathrm{S}$-Sepharose (Pharmacia) pre-equilibrated with extraction buffer (without detergent). After extensive washing the column was eluted with a gradient of $0.2-0.5 \mathrm{M}$ sodium phosphate, $\mathrm{pH}$ $7 \cdot 4$, and $3 \mathrm{ml}$ fractions collected. Those displaying $\mathrm{A}_{430}$ greater than 0.05 were pooled. Preparations such as these typically had an $R_{z}$ of $0.62-0.68$ and displayed one major band (about $65 \mathrm{kd}$ ) on Coomassie stained SDS-PAGE.

PREPARATION OF MYELOPEROXIDASE-SEPHAROSE The myeloperoxidase-Sepharose affinity column was prepared as described in the protocol supplied with the activated Sepharose (Pharmacia). Briefly, $1 \mathrm{~g} \mathrm{CNBr}$ activated Sepharose $6 \mathrm{MB}$ was washed with $0.001 \mathrm{M} \mathrm{HCl}$ and resuspended in $0.1 \mathrm{M} \mathrm{NaHCO}$ containing 0.5 $\mathrm{M} \mathrm{NaCl}$. The Sepharose was mixed by inversion with $15 \mathrm{mg}$ purified myeloperoxidase, and after blockage of residual active sites with $1 M$ ethanolamine was washed with three cycles of $0.1 \mathrm{M}$ acetate, $\mathrm{pH} 4 \cdot 0$, followed by $0.1 \mathrm{M}$ borate, $\mathrm{pH} 8.0$ (both containing $0.5 \mathrm{M} \mathrm{NaCl}$ ).

\section{AFFINITY CHROMATOGRAPHY}

After extensive washing the myeloperoxidaseSepharose was incubated, with mixing, with $1 \mathrm{ml}$ of an inhibitory synovial fluid (diluted to $5 \mathrm{ml}$ with the wash buffer) overnight at $4^{\circ} \mathrm{C}$. The Sepharose was poured into a column and washed thoroughly before elution with $0.1 \mathrm{M}$ acetate buffer, $\mathrm{pH} 4 \cdot 0$, containing $0.5 \mathrm{M} \mathrm{NaCl}$.

\section{Results}

EFFECTS OF SYNOVIAL FLUID AND SERUM ON STIMULUS INDUCED MYELOPEROXIDASE RELEASE The possibility that rheumatoid synovial fluid and serum contain factors able to modulate 
stimulus induced degranulation was investigated by stimulating polymorphonuclear leucocytes with $\mathrm{AMLP}$ in the presence of increasing concentrations of autologous and heterologous synovial fluid and serum. Concentrations of fMLP producing optimal degranulation $(2 \cdot 5 \times$ $10^{-6} \mathrm{~mol} / \mathrm{l}$ ) and suboptimal concentrations producing little or no degranulation $\left(2 \cdot 5 \times 10^{-9}\right.$ $\mathrm{mol} / \mathrm{l}$ ) were used. The results are expressed as a percentage of the control response, which was the response to the stimulus in the absence of synovial fluid or serum. In the first experiment

Table 1 Effect of autologous synovial fluid and serum and normal human serum on $N$-formyl-methionyl-leucyl-phenylalanine induced degranulation*

\begin{tabular}{|c|c|c|c|c|c|c|c|}
\hline \multirow{2}{*}{$\begin{array}{l}\text { Fluid } \\
(\%)\end{array}$} & \multicolumn{3}{|c|}{ Blood polymorphonuclear leucocytes } & \multicolumn{4}{|c|}{ Synovial fluid polymorphonuclear leucocytes } \\
\hline & $\begin{array}{l}\text { Synovial } \\
\text { fluid }\end{array}$ & Serum & $\begin{array}{l}\text { Normal } \\
\text { human } \\
\text { serum }\end{array}$ & $\begin{array}{l}\text { Synovial } \\
\text { fluid }\end{array}$ & Serum & $\begin{array}{l}\text { Normal } \\
\text { human } \\
\text { serum }\end{array}$ & $\begin{array}{l}\text { Osteoarthritic } \\
\text { synovial } \\
\text { fluid }\end{array}$ \\
\hline $\begin{array}{r}1 \\
10 \\
20\end{array}$ & $\begin{array}{l}98(2) \\
76(2) \\
54(2)\end{array}$ & $\begin{array}{l}90(3) \\
20(2) \\
22(2)\end{array}$ & $\begin{array}{r}56(1) \\
18(5) \\
9(3)\end{array}$ & $\begin{array}{l}88(4) \\
65(4) \\
44(4)\end{array}$ & $\begin{array}{l}72(4) \\
18(4) \\
<5\end{array}$ & $\begin{array}{l}50(4) \\
12(2) \\
<5\end{array}$ & $\begin{array}{l}\text { NTt } \\
\text { NT } \\
14(3)\end{array}$ \\
\hline
\end{tabular}

*The results are the means $(\mathrm{SD})$ of triplicate determinations and are expressed as a percentage of the response in the absence of synovial fluid or serum. $+\mathrm{NT}=$ not tested.

Table 2 Effect of rheumatoid sera, synovial fluids, and normal human serum on $N$-formyl-methionyl-leucyl-phenylalanine $(f M L P)$ induced degranulation*

\begin{tabular}{lcccccccc}
\hline $\begin{array}{l}\text { Fluid } \\
(\%)\end{array}$ & SFIt & SF2t & SF3t & SRM1t & SRM2t & SRM3t & NHS1t & NHS2t \\
\hline 1 & 100 & 100 & 100 & 100 & $86(2)$ & 100 & $77(3)$ & 100 \\
10 & $15(3)$ & $84(5)$ & $65(5)$ & $16(2)$ & $5(1)$ & $45(5)$ & $17(6)$ & $20(2)$ \\
20 & $12(1)$ & $60(2)$ & $30(4)$ & $10(3)$ & $5(1)$ & $15(3)$ & $5(3)$ & $6(1)$ \\
\hline
\end{tabular}

${ }^{*}$ Results are the means (SD) of triplicate determinations and are expressed as a percentage of the response to fMLP $\left(2.5 \times 10^{-6} \mathrm{~mol} / \mathrm{l}\right)$ in the absence of serum and synovial fluid.

†SF1, SRM1 = paired synovial fluid and serum (patient 1); SF2, SRM2=paired synovial fluid and serum (patient 2); SF3, SRM3 = paired synovial fluid and serum (patient 3); NHS1, NHS2=normal serum from normal donors.

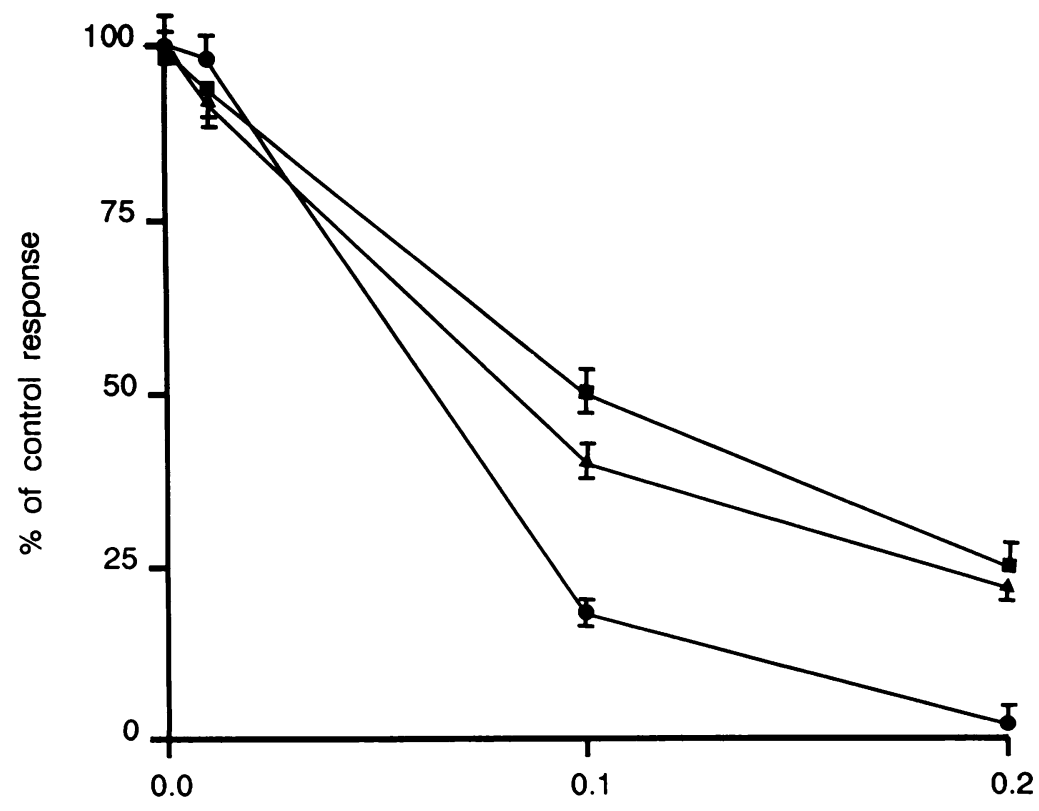

Reciprocal dilution of SF Figure 1 Effect of different stimuli on synovial fluid induced inhibition of
polymorphonuclear leucocyte degranulation. Normal blood polymorphonuclear leucocytes polymorphonuclear leucocyte degranulation. Normal blood polymorphonuclear leucocytes
were stimulated with heat aggregated Ig $(0.5 \mathrm{mg} / \mathrm{ml})(\mathbf{O}), N$-formyl-methionyl-leucylphenylalanine $\left(2.5 \times 10^{6} \mathrm{~mol} / \mathrm{l}\right)(\Delta)$, or platelet activating factor $(2 \cdot 5 \mu \mathrm{g} / \mathrm{ml})(\mathbf{\square})$ in the presence of $10 \%(v / v)$ synovial fluid or human serum albumin-Hanks's balanced salt solution. Myeloperoxidase activity released was measured and expressed as a percentage of myeloperoxidase activity released in the absence of synovial fluids. Results are the means $(S D)$ myeloperoxidase activity released in the absenc
of three measurements. SF= synovial fluid. synovial fluid and blood polymorphonuclear leucocytes from two patients with rheumatoid arthritis were stimulated with $\mathrm{fMLP}\left(2 \cdot 5 \times 10^{-6}\right.$ $\mathrm{mol} / \mathrm{l})$ in the presence of increasing concentrations of autologous synovial fluid and serum, normal human serum, and synovial fluid from a patient with osteoarthritis. Table 1 shows the results for one patient, and similar results were obtained with the other. The degranulation response elicited by fMLP was inhibited in a dose dependent manner, and the degree of inhibition produced by synovial fluid or serum was the same for both the blood and synovial fluid polymorphonuclear leucocytes. The inhibition of myeloperoxidase release by serum was greater than that by synovial fluid. In other experiments it was shown that fMLP induced degranulation of synovial fluid and blood polymorphonuclear leucocytes was suppressed by all autologous synovial fluids $(n=7)$ and sera $(n=9)$ tested, though the degree of inhibition varied between synovial fluids. The response of synovial fluid and blood derived polymorphonuclear leucocytes to a suboptimal dose of fMLP $\left(2.5 \times 10^{-9} \mathrm{~mol} / \mathrm{l}\right)$ was also tested and found to be inhibited in the presence of synovial fluid and serum (data not shown).

The effect of paired rheumatoid synovial fluids, sera, and normal sera on fMLP mediated degranulation by normal blood polymorphonuclear leucocytes was examined. Again all synovial fluids and sera produced dose dependent inhibition of myeloperoxidase release (table 2). Serum was more inhibitory than synovial fluid in two of the three paired samples studied. Normal human serum also inhibited release of myeloperoxidase and was a more potent inhibitor than rheumatoid synovial fluid and in some cases than rheumatoid serum.

STIMULUS SPECIFICITY OF THE INHIBITION EFFECT OF SYNOVIAL FLUID AND SERUM ON MYELOPEROXIDASE RELEASE

To determine whether the inhibition of myeloperoxidase release was dependent on the stimulus eliciting degranulation the effect of increasing concentrations of synovial fluid and serum on platelet activating factor $(2.5 \mu \mathrm{g} / \mathrm{ml})$, heat aggregated $\operatorname{IgG}(0.5 \mathrm{mg} / \mathrm{ml})$, and $\mathrm{fMLP}$ $\left(2.5 \times 10^{-6} \mathrm{~mol} / \mathrm{l}\right)$ mediated release of myeloperoxidase by normal blood polymorphonuclear leucocytes was examined. Two synovial fluids and one normal human serum, known to be potent inhibitors of fMLP induced degranulation, were used. Figure 1 shows the results for one synovial fluid. It can be seen that inhibition of myeloperoxidase release occurred independently of the agent stimulating degranulation.

MECHANISMS OF INHIBITION BY SYNOVIAL FLUID AND SERUM

Synovial fluid and serum may not be inhibiting polymorphonuclear leucocyte degranulation but rather affecting the activity of released myeloperoxidase. To examine this possibility normal blood polymorphonuclear leucocytes were stimulated with $\mathrm{fMLP}$, alone or in the presence of increasing concentrations of synovial 
fluid or serum. Concomitantly, supernatants from polymorphonuclear leucocytes stimulated with IMLP alone were removed and incubated with increasing concentrations of synovial fluid and serum for 30 minutes at $37^{\circ} \mathrm{C}$. All supernatants were removed and assayed for myeloperoxidase. Table 3 shows that synovial fluid and serum both inhibit myeloperoxidase activity in a dose dependent manner regardless of whether cells are present or not.

In subsequent experiments polymorphonuclear leucocytes were stimulated with fMLP $\left(2.5 \times 10^{-6} \mathrm{~mol} / \mathrm{l}\right)$ for 30 minutes and the supernatants used as a source of myeloperoxidase ('myeloperoxidase supernatants'). The effect of five paired rheumatoid synovial fluids and sera, six osteoarthritic synovial fluids, and 10 normal human serum samples (all at concentration of $10 \%)$ on 'myeloperoxidase supernatant' activity was tested. Myeloperoxidase activity (as a percentage of the response in the absence of fluids) was $15,84,65,59$, and $51 \%$ in the presence of rheumatoid synovial fluids and $16,5,45,34$, and 50 in the presence of the paired serum samples. By comparison, the normal human serum gave values of $20,27,10,15,18,30,13$, 12,17 , and $24 \%$ and the osteoarthritic synovial

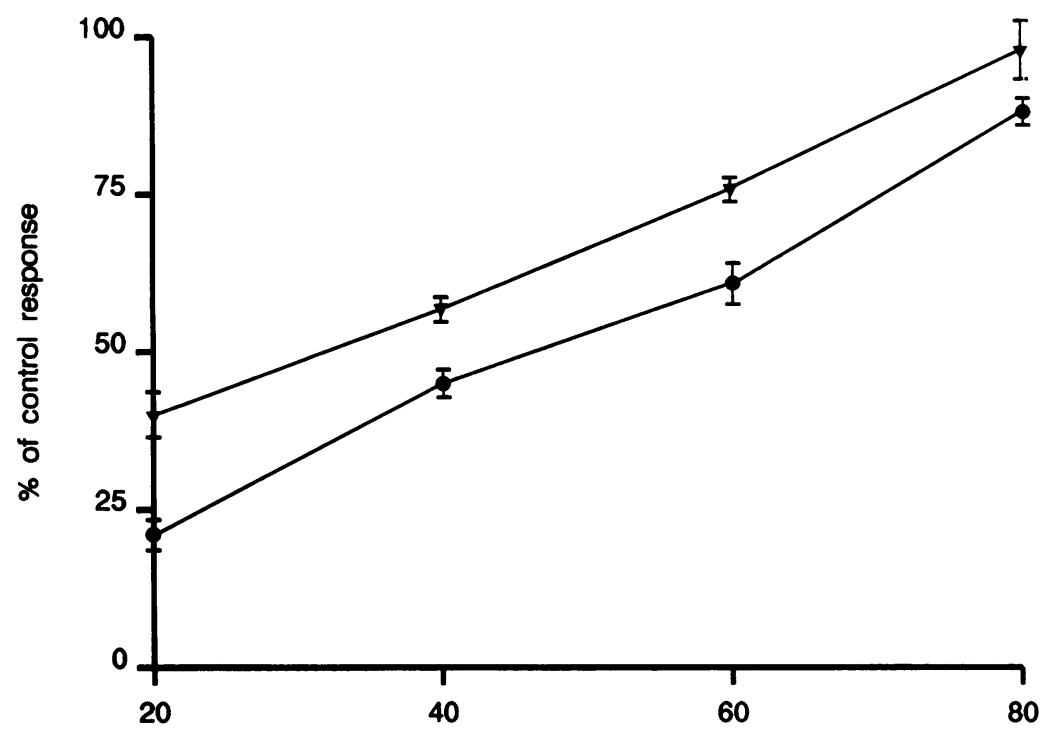

$\mu l \mathrm{MPO}-\mathrm{S}$

Figure 2 Ability of myeloperoxidase to reverse the inhibitory effect of synovial fluid on myeloperoxidase activity. Increasing volumes of 'myeloperoxidase supernatant' (MPO-S) were incubated with a constant volume of $20 \%$ synovial fluid $(v / v)$ or medium alone and the resulting myeloperoxidase activity was measured. Results are expressed as a percentage of the myeloperoxidase activity in the absence of symovial fluid and are the means $(S D)$ of three determinations. $\mathbf{O}=$ synovial fluid $1 ; \boldsymbol{\nabla}=$ synovial fluid 2 .

Table 3 Effect of synovial fluid and serum on myeloperoxidase activity*

\begin{tabular}{|c|c|c|c|c|}
\hline \multirow{2}{*}{$\begin{array}{l}\text { Fluid } \\
(\%)\end{array}$} & \multicolumn{2}{|l|}{ Cells present } & \multicolumn{2}{|l|}{ Cell-free } \\
\hline & SFIt & SRMIt & SFlt & SRMIt \\
\hline $\begin{array}{l}0 \\
0 \cdot 1 \\
1.0 \\
10 \cdot 0 \\
20.0\end{array}$ & $\left.\begin{array}{l}1.9(0.7)[100] \\
1.9(0 \cdot 1)[100] \\
1 \cdot 9(0 \cdot 1)[100] \\
1 \cdot 2(0 \cdot 1)[63] \\
0.8(0 \cdot 1)\end{array}\right]$ & 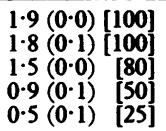 & $\begin{array}{ll}1.9(0.0) & {[100]} \\
1.9(0.1) & {[100]} \\
1.8(0.2) & {[98]} \\
1.0(0.1) & {[54]} \\
0.7(0.1) & {[39]}\end{array}$ & 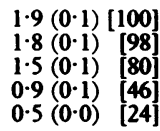 \\
\hline
\end{tabular}

${ }^{*}$ Results are the means (SD) of triplicate determinations and are expressed as the change in absorbance at $655 \mathrm{~nm}$ after five minutes. Figures in square brackets are the results expressed as a percentage of the response in the absence of synovial fluid and serum.

$+\mathrm{SF} 1$, SRM1 = paired synovial fluid and serum from a patient with rheumatoid arthritis. fluids values of $30,58,47,62,56$, and $48 \%$. In another experiment it was found that rheumatoid synovial fluids with low myeloperoxidase activities were most inhibitory and those with higher myeloperoxidase activities were least inhibitory. Synovial fluids with a myeloperoxidase activity of $0.9,0.6,0.2,0.1$, and 0 (absorbance change at $655 \mathrm{~nm}$ after five minutes) produced $33,18,75,82$, and $86 \%$ inhibition respectively.

An experiment was set up to determine whether the inhibitory activity of a constant amount of synovial fluid and serum $(20 \%, v / v)$ could be overcome by adding increasing concentrations of 'myeloperoxidase supernatant'. Figure 2 shows that the inhibitory activity of both synovial fluid and serum was reversed in a dose dependent manner.

The inhibitory activity may be due to some component of synovial fluid or serum interfering non-specifically with the enzyme substrate. To test this possibility the assay substrate was incubated with increasing concentrations of synovial fluid for 30 minutes, after which 'myeloperoxidase supernatant' was added and the enzyme activity compared with substrate incubated with HSA-HBSS. The mean (SD) myeloperoxidase activity of substrate incubated in HSA-HBSS was $1.5(0.1)$ and of substrate incubated in three inhibitory synovial fluids $(20 \%, \mathrm{v} / \mathrm{v})$ was $1 \cdot 3(0 \cdot 1), 1 \cdot 3(0 \cdot 1)$, and $1 \cdot 2(0 \cdot 1)$ (absorbance change at $655 \mathrm{~nm}$ after five minutes) respectively. In other words, incubation of synovial fluid with the enzyme substrate did not inhibit myeloperoxidase activity.

The effect of synovial fluid and serum on $\beta$ glucuronidase activity was tested to determine whether the inhibitory effect was specific for myeloperoxidase. Table 4 shows that whereas myeloperoxidase activity was inhibited in the presence of synovial fluid, $\beta$-glucuronidase activity was unaffected. Similar tests were carried out on 'myeloperoxidase supernatant' with three other rheumatoid synovial fluids and another normal serum. At $10 \%$ concentration the myeloperoxidase activity was 56 (3), 55 (4), $67(3)$, and $23(2) \%$ respectively of that in the absence of the fluids. By contrast, $\beta$-glucuronidase activity in the presence of the fluids remained at $100(3), 95(5), 97(3)$, and $93(8) \%$ of the activity in the absence of the fluids.

EFFECT OF PERIOD OF INCUBATION ON INHIBITION It can be seen that the inhibitory activity of synovial fluid and both rheumatoid and normal

Table 4 Effect of symovial fluid on $\beta$-glucuronidase and myeloperoxidase activities*

\begin{tabular}{lll}
\hline $\begin{array}{l}\text { Synovial } \\
\text { fluid (\%) }\end{array}$ & $\begin{array}{l}\beta-\text { Glucuronidase } \\
(A 405 \text { nm/18 hours })\end{array}$ & $\begin{array}{l}\text { Myeloperoxidase } \\
(A 655 \text { nm/5 minutes })\end{array}$ \\
\hline 0 & $1 \cdot 1(0 \cdot 1)$ & $0 \cdot 8(0 \cdot 1)$ \\
1 & $1 \cdot 2(0 \cdot 1)$ & $0 \cdot 8(0 \cdot 1)$ \\
10 & $1 \cdot 1(0 \cdot 1)$ & $0.5(0 \cdot 1)$ \\
25 & $1 \cdot 3(0 \cdot 1)$ & $0 \cdot 3(0 \cdot 2)$ \\
50 & $1 \cdot 1(0 \cdot 1)$ & $0 \cdot 12(0 \cdot 1)$
\end{tabular}

* Results are the means (SD) of triplicate determinations and are 'Myeloperoxidase supernatant' was incubated with synovial fluid for 30 minutes before assay of the two enzymes. 
sera was dependent on the period for which the fluid was incubated with the enzyme containing supernatant (table 5). The inhibitory effect was apparent within 10 minutes and increased thereafter, reaching a maximum at between 20 and 30 minutes.

PROPERTIES OF MYELOPEROXIDASE INHIBITOR As a first step towards characterising the myeloperoxidase inhibitor the effect of dialysis on the inhibitory activity of synovial fluid was ascertained. Three synovial fluids were tested at one concentration $(10 \%, \mathrm{v} / \mathrm{v})$. The mean (SD) inhibition produced by whole synovial fluids was $66(6), 45(4)$, and $46(3) \%$ and on dialysis was $62(6), 30(7)$, and $40(2) \%$ respectively. Similar results were obtained with serum.

Synovial fluids and sera were heated at $63^{\circ} \mathrm{C}$ for 45 minutes and the effect of increasing concentrations of heat inactivated and untreated synovial fluid on 'myeloperoxidase supernatant' activity determined. Table 6 shows that heat inactivation did not lead to loss of the inhibitory activity in rheumatoid synovial fluid, serum, or normal human serum at any of the concentrations tested.

\section{AFFINITY CHROMATOGRAPHY}

The presence of an inhibitor of myeloperoxidase in synovial fluid and serum from patients with rheumatoid arthritis suggested that these fluids may contain a factor capable of binding directly to myeloperoxidase. This was tested by affinity

Table 5 Effect of period of incubation on the inhibition of myeloperoxidase by synovial fluid and serum*

\begin{tabular}{llllll}
\hline Time (min) & SFIt & SRMIt & NHSt & SF2t & SF3t \\
\hline 2 & $90(2)$ & 46 & $52(2)$ & $45(3)$ & $47(6)$ \\
10 & $45(2)$ & 39 & $39(3)$ & $38(3)$ & $32(3)$ \\
20 & $30(3)$ & 20 & NT‡ & $26(4)$ & $20(2)$ \\
30 & $20(2)$ & 26 & $27(3)$ & $18(2)$ & $14(2)$ \\
60 & $15(2)$ & 20 & $15(3)$ & $16(4)$ & $15(3)$ \\
90 & $15(2)$ & 20 & $15(2)$ & NT & NT \\
\hline
\end{tabular}

${ }^{*}$ Results are the means (SD) of three determinations (SF1, 2 and 3 , and NHS) or of two determinations (SRMI) and are expressed as a percentage of the control response.

tSF1, SRM1 = paired rheumatoid synovial fluid and serum; SF2 SF3=rheumatoid synovial fluids; NHS=normal human serum. $\ddagger \mathrm{NT}=$ not tested.

Table 6 Effect of heat activation on inhibition of "myeloperoxidase supernatant"

\begin{tabular}{|c|c|c|c|}
\hline Fluid (\%) & Untreated fluid & Heat inactiv & vated fluid \\
\hline 0 & $1.66(0 \cdot 1) \quad[100]$ & $1 \cdot 66(0 \cdot 1)$ & [100] \\
\hline $\begin{array}{l}S F 1 t \\
1 \\
10 \\
20\end{array}$ & $\begin{array}{ll}1.30(0.10) & {[78]} \\
0.85(0.10) & {[51]} \\
0.73(0.15) & {[44]}\end{array}$ & $\begin{array}{l}1.41(0.10) \\
0.71(0.15) \\
0.82(0.11)\end{array}$ & $\begin{array}{l}{[84]} \\
{[42]} \\
{[48]}\end{array}$ \\
\hline $\begin{array}{l}S R M I t \\
1 \\
10 \\
20\end{array}$ & $\begin{array}{ll}1.40(0.02) & {[84]} \\
0.80(0.1) & {[50]} \\
0.20(0.1) & {[16]}\end{array}$ & $\begin{array}{l}1.51(0.05) \\
0.82(0.21) \\
0.22(0.10)\end{array}$ & $\begin{array}{l}{[90]} \\
{[45]} \\
{[12]}\end{array}$ \\
\hline $\begin{array}{l}N H S \ddagger \\
1 \\
10 \\
20\end{array}$ & $\begin{array}{ll}0.74(0.1) & {[42]} \\
0.32(0.1) & {[18]} \\
0.22(0.01) & {[9]}\end{array}$ & $\begin{array}{l}0.61(0.10) \\
0.32(0.11) \\
0.23(0.01)\end{array}$ & $\begin{array}{l}{[27]} \\
{[14]} \\
{[8]}\end{array}$ \\
\hline
\end{tabular}

${ }^{*}$ Results are the means (SD) of triplicate determinations and are expressed as the absorbance at $655 \mathrm{~nm}$ after five minutes. Figure in square brackets are results expressed as a percentage of the activity of myeloperoxidase after incubation in medium alone. Paired synovial fluid and serum from patient 1 .

$\ddagger$ Normal human serum.

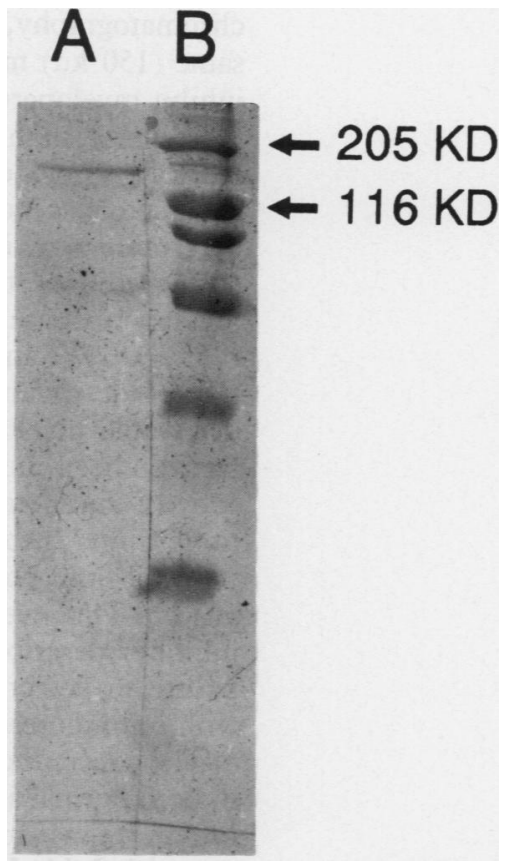

Figure 3 Purification of a myeloperoxidase binding protein by affinity chromatograpy. Myeloperoxidase-Sepharose was prepared and incubated with synovial fluid as described in the 'Patients and methods' section. After extensive washing the Sepharose was eluted with $0 \cdot 1 \mathrm{M}$ sodium acetate $(\mathrm{pH}$ $4 \cdot 0$ ) containing $0.5 \mathrm{M} \mathrm{NaCl}$. This fraction was subjected to sodium dodecyl sulphate-polyacrylamide gel electrophoresis and stained with Coomassie blue (lane A). Lane B shows marker proteins (Sigma, SDS-6H).

chromatography with myeloperoxidase covalently attached to Sepharose. Treatment of the myeloperoxidase-Sepharose with a sample of inhibitory synovial fluid and elution with low $\mathrm{pH}$ buffer yielded essentially a single band on SDS-PAGE when visualised by Coomassie blue, with a molecular weight of about $150 \mathrm{kd}$ (fig 3).

\section{Discussion}

This study describes a novel inhibitor of myeloperoxidase which has been shown to be present in normal and rheumatoid serum and in rheumatoid synovial fluid. Initially, it was found that stimulus induced myeloperoxidase release in the presence of synovial fluid seemed to be inhibited, as indicated by the reduced myeloperoxidase activity, and that the inhibition was not stimulus specific. The latter observation led us to determine whether the decreased activity was due to inhibition of the released enzyme rather than due to inhibition of degranulation. This expectation was borne out by results which showed that there was no inhibition of stimulus induced degranulation but that the enzyme was inhibited by a component of synovial fluid. The inhibitor was found to act only on myeloperoxidase and not on $\beta$-glucuronidase, suggesting specificity. One protein of $M_{r} 150 \mathrm{kd}$ was purified from synovial fluid by affinity chromatography on myeloperoxidaseSepharose, indicating that this protein binds to myeloperoxidase and may therefore be the inhibitor. Work to be reported elsewhere validates this hypothesis. Serum was separated by salt fractionation, ion exchange, and protein $\mathrm{A}$ 
chromatography, and a purified protein of the same $(150 \mathrm{kd})$ molecular weight was shown to inhibit myeloperoxidase activity.

Recently, it has been shown that immunoreactive myeloperoxidase can be detected in rheumatoid synovial fluid in the absence of detectable peroxidase activity, ${ }^{14}$ and it has been suggested that this is owing to inhibition of myeloperoxidase by superoxide and derived radicals. ${ }^{15}$ We and others, however, have shown that most rheumatoid synovial fluids contain detectable myeloperoxidase activity, ${ }^{916}$ and it has also been shown that those with the highest activity can often stimulate superoxide production from rheumatoid (and normal blood) synovial fluid polymorphonuclear leucocytes in vitro. ${ }^{17}$ Thus we consider that presence of the inhibitor described here may better explain the failure to detect peroxidase activity associated with immunoreactive myeloperoxidase.

The concentrations of the inhibitor were high in both normal and rheumatoid serum but were lower by as much as $90 \%$ in rheumatoid synovial fluid. It is known that the molecular weight of proteins influences their access to joints, ${ }^{18}$ even the rheumatoid joint. The molecular weight of the inhibitor $(150 \mathrm{kd})$, however, is such that restricted entry to the joint is only likely to make a small contribution to the low inhibitory activity noted. Alternatively, the low activity may be due to the fact that the inhibitor exists in rheumatoid synovial fluid complexed to myeloperoxidase. It follows that the rheumatoid synovial fluids with high myeloperoxidase concentrations should have low inhibitor concentrations, a prediction supported by the results.

It may be asked how the inhibitor functions biologically. The enzyme myeloperoxidase once released from polymorphonuclear leucocytes exerts no deleterious effects itself, but in combination with hydrogen peroxide, which can arise in the vicinity of cells undergoing the respiratory burst, it gives rise to powerful, highly reactive oxidants. ${ }^{19}$ Such products are highly desirable within phagosomes where they contribute to bacterial killing. In contrast, their presence extracellularly, as in the rheumatoid joint, may be highly damaging. Here myeloperoxidase (which as already mentioned is found at high concentration in a number of rheumatoid synovial fluids) would, in the presence of cells releasing superoxide anions, favour the production of agents which in vitro have been shown to activate the enzymes collagenase $^{20}$ and gelatinase ${ }^{21}$ to inactivate protective antiproteases, ${ }^{22}$ and disrupt the integrity of endothelial tissue. ${ }^{23}$ Thus the myeloperoxidase inhibitor described may be one of an array of antioxidant mechanisms present in serum preventing myeloperoxidase catalysing reactions which would release reactive products under inappropriate conditions.

We thank Professor P A Dieppe and Dr J Kirwan for their help. The work was supported by a grant from the MRC.

1 Palmer D G. Total leukocyte enumeration in pathogenic synovial fluids. Am $\mathcal{F}$ Clin Pathol 1968; 49: 812-4.

2 Oronsky A L, Perper R J. Connective tissue-degrading enzymes of human leukocytes. Ann N Y Acad Sci 1975, 256: 233-53.

3 Baggiolini M, Schnyder J, Bretz U. Lysosomal enzymes and neutral proteinases as mediators of inflammation. Advances in Inflammatory Research 1979; 1: 263-72.

4 Burkhardt H, Schwingel M, Menninger M, Macartney H W Tschesche $\mathrm{H}$. Superoxide radicals as effectors of cartilage Tschesche H. Superoxide radicals as effectors of
destruction. Arthritis Rheum 1986; 29: 379-87.

5 Destruction. Arthritis Rheum 1986; 29: 379-87. response of polymorphonuclear leukocytes from synovial fluids of patients with rheumatoid arthritis. Autoimmunity 1988; 1: 159-69.

6 Fontana A, Hengartner H, Weber E, Fehr K, Grob P J Cohen $G$. Interleukin 1 activity in the synovial fluid of patients with rheumatoid arthritis. Rheumatol Int 1982; 2 : 49-53.

7 Wood D D, Ihrie E J, Hamerman D. Release of interleukin-1 from synovial tissue in vitro. Arthritis Rheum 1985; 28: 853-62.

8 Dularay B, Elson C J, Clements-Jewery S, Damais C, Lando $D$. Recombinant human interleukin $1 \beta$ primes polymorD. Recombinant human interleukin $1 \beta$ primes polymorphonuclear leukocytes for stimulus induced my

9 Dularay B, Dieppe P A, Elson C J. Depressed degranulation response of synovial fluid polymorphonuclear leukocytes from patients with rheumatoid arthritis. Clin Exp Immuno 1990; 79: 195-201

10 Dooley D C, Simpson J F, Meryman H T. Isolation of large numbers of fully viable human neutrophils: a preparative technique using percoll density gradient centrifugation. Exp Hematol 1982; 10: 591-9.

11 Suzuki K, Ota H, Sasagawa S, Sakatani T, Fujikura T. Assay method for myeloperoxidase in human polymorphonuclear

12 Talalay $P$, Fishman $W \mathrm{H}$, Huggins $C$. Chromogenic substrates II. Phenophthalein ghucuronic acid as substrate for the II. Phenophthalein ghucuronic acid as substrate for the
assay of glucuronidase activity. $\mathcal{B}$ Biol Chem 1946; 166: assay of

13 Laemmli U K. Cleavage structural proteins during the assembly of the head of bacteriophage T4. Nature 1970; 227: $680-5$.

14 Edwards S W, Hughes V, Barlow J, Bucknall R. Immunological detection of myeloperoxidase in synovial fluid from patients with rheumatoid arthritis. Biochem $\mathcal{f} 1988 ; 250$ : 81-5.

15 Edwards S W, Nurcombe H L, Hart C A. Oxidative inactivation of myeloperoxidase released from human neutrophils. Biochem 7 1987; 245: 925-8.

16 Hadler N M, Spitznagel J K, Ounet R J. Lysosomal enzymes in inflammatory synovial effusions. $\mathcal{F}$ Immunol 1979; 123: in inflam.

17 Dularay B, Badesha J S, Dieppe P A, Elson C J. Oxidative response of polymorphonuclear leucocytes to synovia fluids from patients with rheumatoid arthritis. Ann Rheum Dis 1990; 49: 661-4.

18 Levick J R. Permeability of rheumatoid and normal human synovium to specific plasma proteins. Arthritis $R$ heum 1981 24: $1550-60$.

19 Klebanoff S J, Clark R A. The neutrophil, function and clinical disorders. Amsterdam: Elsevier/Hollander, 1978: 123-56.

20 Weiss S J, Peppin G, Ortiz Z, Ragsdale C, Test S T. Oxidative activation of latent collagenase by human neutrophils. Science 1985; 227: 747-9.

21 Peppin G J, Weiss S J. Activation of the endogenous metalloproteinase, gelatinase, by triggered human neutrometalloproteinase, gelatinase, by triggered human

22 Ossanna P J, Test S T, Matheson N R, Regiani S, Weiss S J. Oxidative regulation of neutrophil elastase- $\alpha$-1-proteinase inhibitor interactions. F Clin Invest 1986; 77: 1939-51.

23 Weiss S J, Regiani S. Neutrophils degrade sub-endothelial matrices in the presence of alpha-1-proteinase inhibitor. Cooperative use of lysosomal proteinases and oxygen metabolites. F Clin Invest 1984; 73: 1297-303. 